\title{
SPESIFIKASI KEBUTUHAN PERANGKAT LUNAK SISTEM INFORMASI BERITA DENGAN STANDARD ISO/IEC/IEEE 29148:2018
}

\section{SOFTWARE REQUIREMENTS SPECIFICATION OF NEWS INFORMATION SYSTEM WITH STANDARD ISO/IEC/IEEE 29148:2018}

Aulia Putri Restu
Rahayu $^{1}$
Universitas Ma Chung,
Indonesia $^{1}$
email:
auliaputri2311@gmail.c
om

Abstrak: TVRI Sulawesi Tengah merupakan lembaga yang bergerak dibidang penyiaran publik, serta mempunyai tugas untuk memberikan pelayanan informasi, pendidikan, hiburan yang sehat, kontrol dan perekat sosial. Memiliki siaran lokal yang beragam membuat TVRI Sulawesi Tengah dituntut untuk update dalam memberikan informasi setiap harinya. Kenyataannya dalam aktivitas sehari-hari, pendistribusian naskah dan list berita masih dilakukan secara manual yaitu mengandalkan Microsoft Word dan Microsoft Excel serta pendistribusian item berita yang berisikan video atau gambar hasil liputan reporter dan kameramen yang sudah di edit dengan menambahkan hasil dubbing dari dubber di distribusikan mengandalkan hard disk yang sewaktu-waktu bisa terserang virus dan akhirnya data yang di dalam tidak dapat terbaca oleh komputer. Oleh karena itu untuk memudahkan proses operasional, diperlukan analisis kebutuhan perangkat lunak sistem informasi berita untuk menganalisis kebutuhan dari perangkat lunak sistem informasi yang diperlukan sesuai dengan proses bisnis yang sedang berlangsung. Analisis kebutuhan perangkat lunak sistem informasi berita ini menggunakan outline dari Software Requirements Specification standar ISO/IEC/IEEE 29148:2018. Analisis kebutuhan yang dilakukan menghasilkan enam (6) menu antara lain tambah naskah baru, review naskah, data naskah, list berita, data list berita, gambar berita, data gambar berita dan siaran siap tayang.

Kata Kunci: Sistem informasi berita, perangkat lunak, Software Requirements Specification, ISO/IEC/IEEE 29148:2018.

Abstract: TVRI Central Sulawesi is an institution engaged in public broadcasting, and has the task of providing information services, education, healthy entertainment, control and social glue. Having a variety of local broadcasts makes TVRI Central Sulawesi required to update in providing information every day. In fact, in daily activities, the distribution of scripts and news lists is still done manually by relying on Microsoft Word and Microsoft Excel as well as the distribution of news items containing videos or images from reporters and cameramen that have been edited by adding dubbing results from the dubber, distributed rely on the hard disk which at any time can be attacked by viruses and ultimately the data inside cannot be read by the computer. Therefore, to facilitate the operational process, it is necessary to analyze the needs of news information system software to analyze the needs of the required information system software in accordance with ongoing business processes. This news information system software requirements analysis uses the outline of the ISO/IEC/IEEE 29148:2018 Software Requirements Specification standard. The needs analysis carried out resulted in six (6) menus, including adding new scripts, reviewing scripts, script data, news lists, news list data, news images, news image data and broadcasts ready to air.

Keywords: News information system, software, Software Requirements Specification, ISO/IEC/IEEE 29148:2018.

\section{PENDAHULUAN}

Kebutuhan akan berita saat ini masih diperlukan oleh semua kalangan. Baik berita dalam negeri maupun luar negeri. Berita dapat diartikan sebagai laporan terkini tentang fakta atau pendapat yang penting atau menarik bagi khalayak dan disebar luaskan melalui media masa (Yosef, 2009). Namun berita yang dicari oleh seorang reporter sebuah laporan tentang fakta yang terlibat dalam suatu peristiwa, namun bukan hakiki dari peristiwa itu sendiri (Winarni \& Lestari, 2019).
Salah satu Lembaga penyiaran yang masih eksis sampai saat ini adalah Lembaga Penyiaran Publik Televisi Republik Indonesia atau di singkat dengan LPP TVRI yang merupakan jaringan televisi publik berskala nasional di Indonesia. Sebagai televisi publik, dalam hai ini LPP TVRI mempunyai tugas untuk memberikan pelayanan informasi, pendidikan, hiburan yang sehat, kontrol dan perekat sosial, serta melestarikan budaya bangsa untuk kepentingan seluruh lapisan masyarakat melalui penyelenggaraan 
penyiaran televisi yang menjangkau seluruh wilayah Negara Kesatuan Republik Indonesia.

TVRI mempunyai jangkauan stasiun di setiap wilayah Indonesia, sehingga setiap wilayah memiliki 2 jenis siaran, yaitu siaran nasional dan siaran lokal. TVRI Sulawesi Tengah merupakan salah satu yang bertempat di kota Palu. Memiliki siaran lokal yang beragam membuat TVRI Sulawesi Tengah dituntut untuk update dalam memberikan informasi setiap harinya. Kenyataannya dalam aktivitas sehari-hari, pendistribusian naskah dan list berita masih dilakukan secara manual yaitu mengandalkan Microsoft Word dan Microsoft Excel kemudian di cetak, serta pendistribusian item berita yang berisikan video atau gambar hasil liputan reporter dan kameramen yang sudah di edit dengan menambahkan hasil dubbing dari dubber, di distribusikan mengandalkan hard disk yang sewaktu-waktu bisa terserang virus dan akhirnya data yang di dalam tidak dapat terbaca oleh komputer.

Untuk meningkatkan operasional harian dalam pembuatan naskah dan pendistribusian berita maka dibutuhkan sebuah sistem informasi berbasis website yang dapat mempermudah dalam pekerjaan. Sistem informasi terdiri dari satuan komponen yang saling berhubungan yang mengumpulkan, memproses, menyimpan, dan mendistribusikan informasi untuk mendukung pengambilan keputusan dalam suatu organsasi (Melinda, Borman, \& Susanto, 2017).

Salah satu metode pengembangan perangkat lunak atau disebut System Development Life Cycle adalah dengan model waterfall (model linear sequential) merupakan model klasik bersifat sistematis, yang digunakan sebagai acuan dalam mengembangkan suatu proyek yang inovatif dan kompleks (Fridayanthie \& Mahdianti, 2016).
Sebuah sistem infromasi yang baik didalamnya ada analisis kebutuhan serta perancangan sistem untuk memudahkan dalam mengidentifikasi kebutuhan. Analisa kebutuhan merupakan bagian dari rekayasa perangkat lunak yang menitik beratkan pada tujuan, fitur atau fungsi kegunaan dan batasan yang ada pada sistem perangkat lunak (Yasin, MZ, \& Fitriyadi, 2015) serta dilakukan untuk membantu menjabarkan kebutuhan pengguna terkait dengan sistem yang akan dibangun atau dikembangkan (Prayitno \& Safitri, 2015).

Tahap analisis dilakukan dengan menganalisis sistem secara fungsional dan non fungsional, secara fungsional berarti menganalisis kebutuhan yang berisi proses atau layanan yang disediakan oleh sistem, sedangkan secara non-fungsional berarti menganalisis kebutuhan yang diperlukan untuk mendukung operasional sistem (Pujianto, 2012).

Non-fungsional sangat berkaitan erat dengan aspek kualitas perangkat lunak sehingg memiliki peran yang sangat besar untuk mendukung kesuksesan pengembangan perangkat lunak (Hakim, Rochimah, \& Fatichah, 2019)

Kemudian pada tahap perancangan sistem dilakukan dengan membuat use case diagram dan activity diagram. Use case diagram menggambarkan bagaimana sistem berinteraksi dengan lingkungannya melalui ilustrasi aktifitas yang dilakukan oleh pengguna dan respon dari sistem (Faslah, Satria, \& Samponu, 2017).

Sehingga untuk melakukan analisis perangkat lunak sistem informasi menggunakan outline dari SoftwareRequirements Specification standar ISO/IEC/IEEE 29148:2018.

\section{METODE}

Pada bagian ini, metode yang digunakan yaitu mengimplementasikan Software Requirements Specification standar 
ISO/IEC/IEEE 29148:2018 yang berisikan ketentuan untuk proses dan produk yang terkait dengan rekayasa persyaratan untuk sistem dan produk perangkat lunak di sepanjang siklus hidup. Dokumen ini memberikan rincian atribut dan karakteristik persyaratan dalam konteks sistem dan rekayasa perangkat lunak. Dokumen ini juga memberikan panduan tambahan dalam penerapan proses rekayasa dan manajemen persyaratan dalam ISO ISO/IEC/IEEE 12207 dan ISO/IEC/IEEE 15288. Terakhir, dokumen ini mengidentifikasi item informasi yang terkait dengan rekayasa persyaratan dan isinya (IEEE, 2018).

Dokumen ini meliputi Purpose, Scope, Product Perspective, Product Functions, User Characteristics, Limitations, Specified Requirement, Functions, Performance Requirements, Usability Requirements, Interface Requirements, Logical Database Requirements, dan Supporting Information.

Alur kerja pada bagian ini dimulai dari tahap identifikasi masalah dan perumusan masalah, kemudian menentukan batasan masalah. Selanjutnya dilakukan studi lapangan berupa wawancara serta observasi dan studi literatur. Seluruh data yang dikumpulkan kemudian diolah untuk menghasilkan dokumen kebutuhan perangkat lunak sesuai dengan standar dokumen SRS ISO/IEC/IEEE 29148:2018.

\section{HASIL DAN DISKUSI}

Pembuatan analisis kebutuhan perangkat lunak pada Sistem Informasi Berita LPP TVRI Sulawesi Tengah mengacu pada proses bisnis yang sedang berjalan di Divisi Redaksi. Dari hasil pemetaan proses bisnis tersebut, dapat menghasilkan pemetaan menu dan sub menu pada sistem informasi berita. Berikut merupakan jabaran dari setiap menu pada Sistem Informasi Berita:

1. Menu Tambah Naskah Baru

2. Menu Review Naskah
a. Sub Menu Naskah Baru

b. Sub Menu Naskah Disetujui

c. Sub Menu Naskah Ditolak

d. Sub Menu Naskah Sudah Direvisi

e. Sub Menu Arsip Naskah

3. Menu Data Naskah

a. Sub Menu Naskah Disetujui

b. Sub Menu Naskah Ditolak

c. Sub Menu Naskah Direvisi

d. Sub Menu Naskah Revisi Diterima

4. Menu List Berita Harian

a. Sub Menu Tambah List Berita

b. Sub Menu Data List Berita

5. Menu Gambar Berita

a. Sub Menu Tambah Gambar Berita

b. Sub Menu Data Gambar Berita

6. Menu Siaran Siap Tayang

Untuk kerangka dokumen SRS mengacu pada SRS Outline standar ISO/IEC/IEEE - 29148:2018. Outline SRS meliputi bagian-bagian berikut:

\section{Gambar 1}

SRS Outline

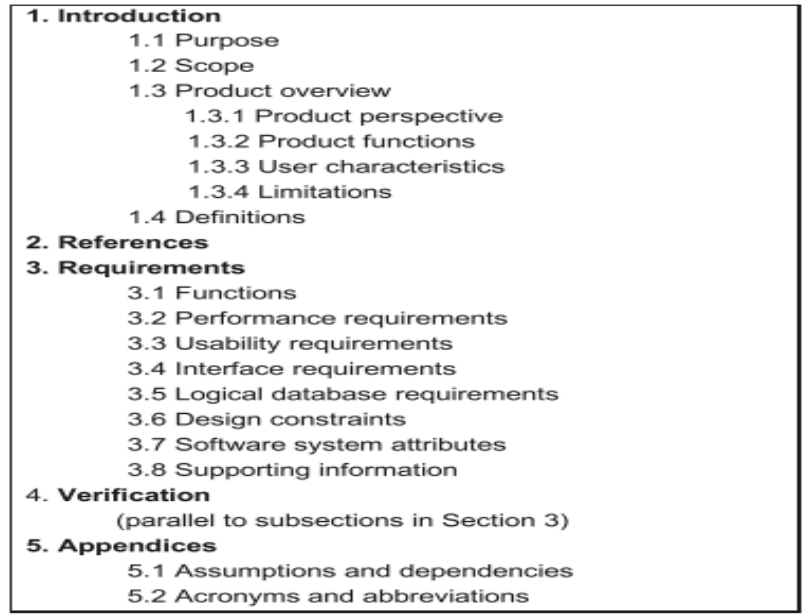

Berikut merupakan hasil Software Requirements Specification (SRS) untuk Menu List Berita Harian, sub menu list berita harian berisikan aktivitas menyusun judul-judul berita yang siap untuk di siarkan. Menu lainnya pada Sistem Informasi Berita ini dipaparkan dalam dokumen yang terpisah.

\section{Introduction}

\subsection{Purpose}

Tujuan pembuatan menu List Berita Harian adalah untuk membantu pengguna dalam melakukan aktivitas penyusunan judul- 
judul berita yang sudah lolos review kemudian siap untuk disiarkan.

\subsection{Scope}

Ruang lingkup dalam menu list berita harian membahas kebutuhan perangkat lunak sistem informasi berita pada bagian perencanaan siaran.

\subsection{Product Overview}

\subsubsection{Product Perspective}

Menu list berita harian merupakan bagian dari proses bisnis perencanaan siaran. Menu ini memiliki keterkaitan dengan menu gambar berita yang berperan untuk menambahkan gambar berita dalam perencanaan siaran. Dan nantinya menu ini berkaitan dengan menu siaran siap tayang untuk di ambil datanya dan siap dipublikasikan.

\subsubsection{Product Functions}

Menu list berita harian merupakan menu yang mengatur proses pembuatan list berita harian untuk operasional siaran. Menu ini bertujuan untuk menyusun judul-judul berita yang sudah disetujui dan sudah dilakukan revisi oleh reporter. Menu ini memiliki sub menu, yaitu:

Sub Menu Tambah List Berita, berfungsi untuk menambahkan data judul berita dan disusun untuk menentukan urutan tayang. Jumlah judul berita untuk sekali siaran perhari kurang lebih 15 judul sampai 20 judul.

Sub Menu Data List Berita, berfungsi menampilkan data judul berita yang sudah disusun sesuai urutan tayang. Jika ada perbaikan atau penghapusan judul berita yang tidak akan ditayangkan, sub menu ini fungsi untuk melakukan edit dan juga delete. Kemudian data list berita akan di masukkan gambar yang sudah dilakukan proses editing oleh editor. Sub menu ini terintegrasi dengan sub menu tambah list berita.

\subsubsection{User Characteristic}

Bagian ini menjelaskan semua pengguna (user) yang terlibat dalam menu ini.
Pengguna (user) tersebut diantaranya adalah redaktur selaku penanggung jawab siaran.

\subsubsection{Limitations}

Modul ini hanya mencakup prosedur fungsi penyusunan judul-judul berita yang siap tayang. Modul ini dapat mengambil data arsip naskah yang merupakan hasil review naskah yang disetujui dan sudah direvisi oleh reporter, lalu membuat penyusunan juduljudul berita dan nanti dilengkapi dengan gambar berita.

\section{Requirement}

\subsection{Functions}

Aktivitas yang dilakukan pengguna untuk memproses input pada sistem agar menghasilkan output, digambarkan dalam use case diagram dan activity diagram.

Gambar 2

Use Case Diagram Sub Menu Tambah List Berita

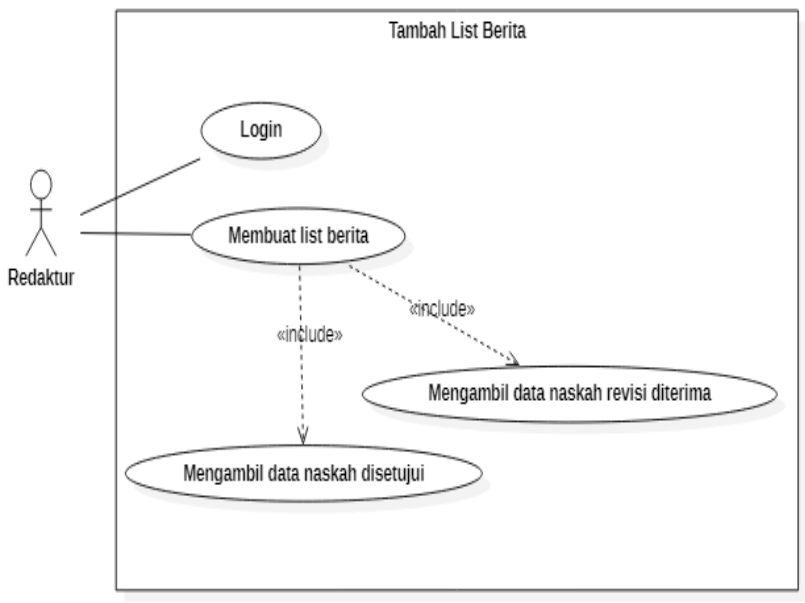

Gambar 3

Activity Diagram Sub Menu Tambah List Berita

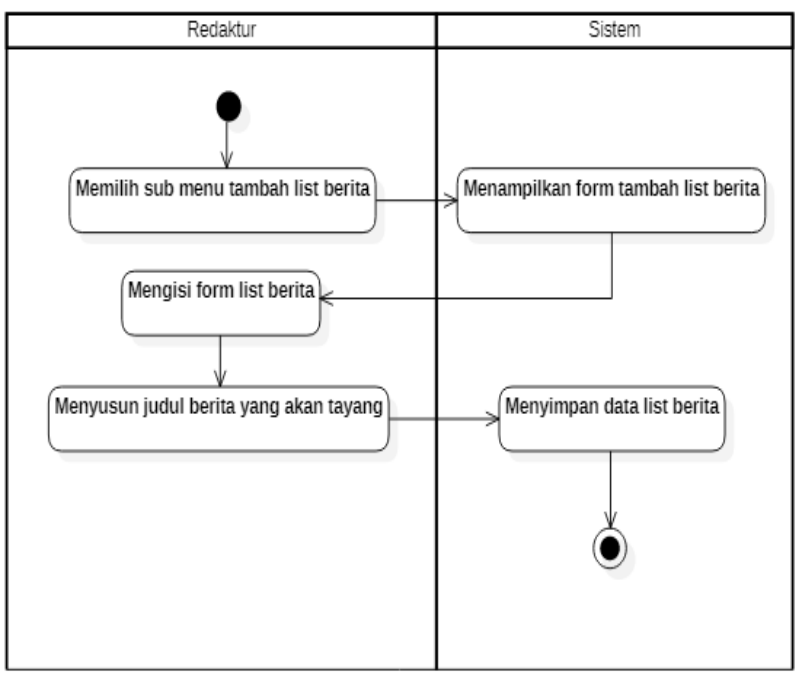




\section{Gambar 4}

Use Case Diagram Sub Menu Data List Berita

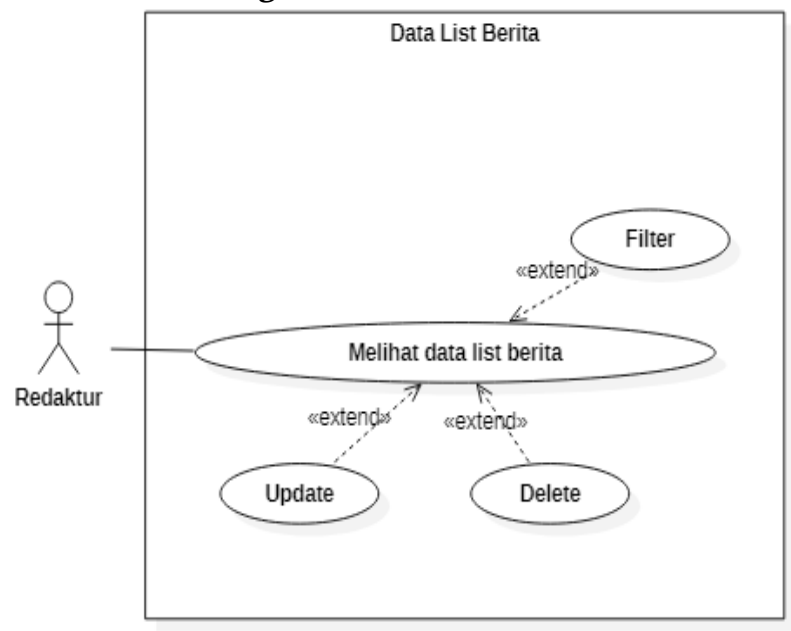

Gambar 5

Activity diagram sub menu data list berita

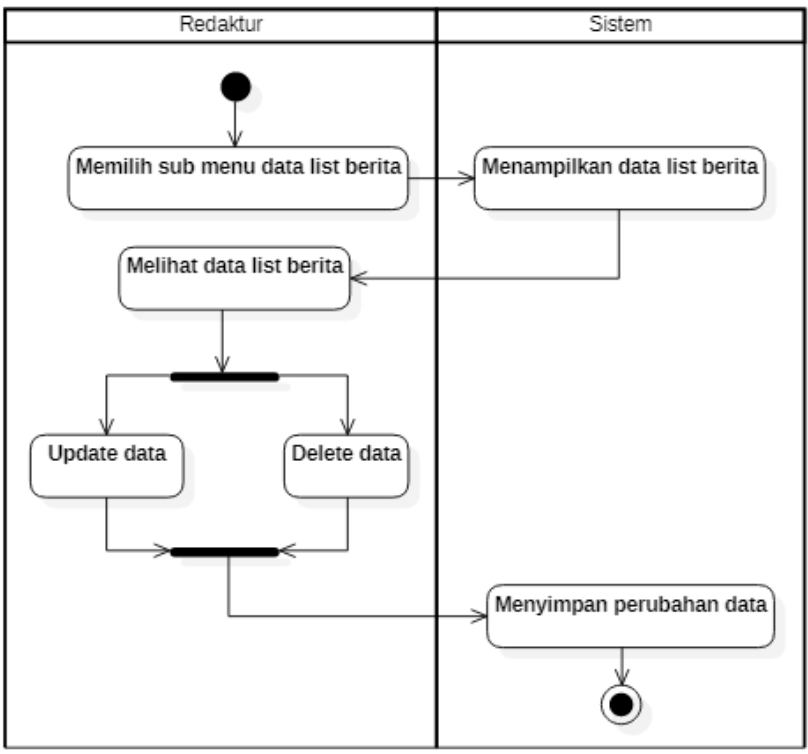

\subsection{Functional Requirement}

Tabel 1

Functional Requirement Sub Menu Tambah List Berita

\begin{tabular}{|c|c|c|c|c|}
\hline \multirow{2}{*}{ No } & \multirow{2}{*}{$\begin{array}{l}\text { Kode } \\
\text { User }\end{array}$} & \multirow{2}{*}{ Deskripsi Kebutuhan } & \multicolumn{2}{|c|}{ Fungsional } \\
\hline & & & User & Sistem \\
\hline 1 & R2 & User melakukan Log-in ke dalam sistem & $\checkmark$ & \\
\hline 2 & $\mathrm{R} 2$ & $\begin{array}{l}\text { User menginputkan data sesuai form yang } \\
\text { diberikan }\end{array}$ & & \\
\hline 3 & $\mathrm{R} 2$ & $\begin{array}{l}\text { User melakukan penvusunan list berita } \\
\text { sesuai dengan judul naskah yang disetujui } \\
\text { dan yang sudah direxisi }\end{array}$ & $\checkmark$ & \\
\hline 4 & & $\begin{array}{l}\text { Sistem memeriksa data Log-in sesuai } \\
\text { dengan hak akses }\end{array}$ & & $\checkmark$ \\
\hline 5 & & $\begin{array}{l}\text { Sistem dapat menampilkan data iudul } \\
\text { naskah }\end{array}$ & & $\checkmark$ \\
\hline 6 & & $\begin{array}{l}\text { Sistem menyimpan seluruh data yang di } \\
\text { input oleh user ke database }\end{array}$ & & $\checkmark$ \\
\hline
\end{tabular}

Tabel 2

Functional Requirement Sub Menu Data List Berita

\begin{tabular}{|c|c|c|c|c|}
\hline \multirow{2}{*}{$\mathrm{N}_{0}$} & \multirow{2}{*}{$\begin{array}{l}\text { Kode } \\
\text { User }\end{array}$} & \multirow{2}{*}{ Deskripsi Kebutuhan } & \multicolumn{2}{|c|}{ Fungsional } \\
\hline & & & User & Sistem \\
\hline 1 & $\mathrm{R} 2$ & User melakukan Log-in ke dalam sistem & $\checkmark$ & \\
\hline 2 & $\mathrm{R} 2$ & User dapat melihat data list berita & $\checkmark$ & \\
\hline 3 & $\mathrm{R} 2$ & $\begin{array}{l}\text { User dapat melakukan Read, Update dan } \\
\text { Delete }\end{array}$ & $\checkmark$ & \\
\hline 4 & & $\begin{array}{l}\text { Sistem memeriksa data Log-in sesuai } \\
\text { dengan hak akses }\end{array}$ & & $\checkmark$ \\
\hline 5 & & Sistem menximpan data ke database & & $\checkmark$ \\
\hline
\end{tabular}

\subsection{Non-functional Requirement}

Tabel 3

Non-functional Requirement Sub Menu Tambah List Berita

\begin{tabular}{|c|c|c|c|}
\hline Komponen & Keterangan & $\begin{array}{l}\text { Enable/ } \\
\text { Disable }\end{array}$ & Fungsi \\
\hline Siaran & Berisi nama siaran & Enable & Text field \\
\hline Tanggal & $\begin{array}{l}\text { Digunakan untuk memasukkan tanggal } \\
\text { tayang siara }\end{array}$ & Enable & Date \\
\hline Waktu & $\begin{array}{l}\text { Digunakan untuk memasukkan waktu } \\
\text { tayang siaran }\end{array}$ & Enable & Time \\
\hline PD & $\begin{array}{l}\text { Merupakan pilihan PD yang bertugas saat } \\
\text { siaran }\end{array}$ & Enable & $\begin{array}{l}\text { Combo } \\
\text { box }\end{array}$ \\
\hline FD & $\begin{array}{l}\text { Merupakan pilihan FD yang bertugas saat } \\
\text { siaran }\end{array}$ & Enable & $\begin{array}{l}\text { Combo } \\
\text { box }\end{array}$ \\
\hline Host & $\begin{array}{l}\text { Merupakan pilihan untuk host yang akan } \\
\text { membawakan acara }\end{array}$ & Enable & $\begin{array}{l}\text { Combo } \\
\text { box }\end{array}$ \\
\hline $\begin{array}{l}\text { Tambah list } \\
\text { berita }\end{array}$ & $\begin{array}{l}\text { Merupakan fungsi untuk membuat list } \\
\text { berita }\end{array}$ & Enable & $\begin{array}{l}\text { Add } \\
\text { button }\end{array}$ \\
\hline $\begin{array}{l}\text { Tabel } \\
\text { tambah data } \\
\text { list berita }\end{array}$ & $\begin{array}{l}\text { Merupakan tabel untuk menampilkan } \\
\text { informasi yang dibutuhakn untuk membuat } \\
\text { list berita }\end{array}$ & Disable & Output \\
\hline Judul berita & $\begin{array}{l}\text { Merupakan pilihan judul berita sesuai } \\
\text { dengan hasil arsip naskah yang diverifikasi }\end{array}$ & Enable & $\begin{array}{l}\text { Combo } \\
\text { box }\end{array}$ \\
\hline Reporter & $\begin{array}{l}\text { Merupakan fungsi menampilkan nama } \\
\text { reporter yang bertugas meliput berita } \\
\text { tersebut }\end{array}$ & Disable & Output \\
\hline Kameramen & $\begin{array}{l}\text { Merupakan fungsi menampilkan nama } \\
\text { kameramen yang bertugas meliput berita } \\
\text { tersebut }\end{array}$ & Disable & Output \\
\hline Keterangan & $\begin{array}{l}\text { Merupakan fungsi untuk menambahkan } \\
\text { keterangan pada judul berita yang dipilih }\end{array}$ & Enable & Text field \\
\hline Simpan & Digunakan untuk menyimpan data & Enable & Button \\
\hline Batal & $\begin{array}{l}\text { Digunakan untuk } \\
\text { penyimpanan data }\end{array}$ & Enable & Button \\
\hline
\end{tabular}




\section{Tabel 4}

\begin{tabular}{|c|c|c|c|}
\hline Komponen & Keterangan & Enable/Disable & Fungsi \\
\hline Show entries & $\begin{array}{l}\text { Merupakan pilihan } \\
\text { jumlah berapa banyak } \\
\text { data yang ditampilkan }\end{array}$ & Enable & Number stepper \\
\hline $\begin{array}{l}\text { Tabel list } \\
\text { berita }\end{array}$ & $\begin{array}{l}\text { Merupakan table } \\
\text { yang berisikan } \\
\text { informasi list berita }\end{array}$ & Disable & Output \\
\hline Search bar & $\begin{array}{l}\text { Merupakan fungsi } \\
\text { untuk mencari data } \\
\text { pada tabel list berita }\end{array}$ & Enable & Search bar \\
\hline $\begin{array}{l}\text { Lihat list } \\
\text { berita }\end{array}$ & $\begin{array}{l}\text { Digunakan untuk } \\
\text { menampilkan isi list } \\
\text { berita }\end{array}$ & Enable & View button \\
\hline Edit button & $\begin{array}{l}\text { Digunakan untuk } \\
\text { mengedit data }\end{array}$ & Enable & Button \\
\hline Delete button & $\begin{array}{l}\text { Digunakan untuk } \\
\text { menghapus data }\end{array}$ & Enable & Button \\
\hline Simpan & $\begin{array}{l}\text { Digunakn untuk } \\
\text { menyimpan data }\end{array}$ & Enable & Button \\
\hline Batal & $\begin{array}{l}\text { Digunakan untuk } \\
\text { membatalkan } \\
\text { penyimpanan data }\end{array}$ & Enable & Button \\
\hline Scroll & $\begin{array}{l}\text { Digunakan untuk } \\
\text { navigasi atas dan } \\
\text { bawah pada tabel list } \\
\text { berita }\end{array}$ & Enable & Scroll bar \\
\hline $\begin{array}{l}\text { Previous and } \\
\text { next }\end{array}$ & $\begin{array}{l}\text { Digunakan untuk } \\
\text { menampilkan } \\
\text { halaman sebelumnya } \\
\text { atau selanjutnya }\end{array}$ & Enable & $\begin{array}{l}\text { Previous and next } \\
\text { button }\end{array}$ \\
\hline
\end{tabular}

\subsection{Logical Database Requirement} Gambar 6

Desain Logical Database Menu List Berita Harian

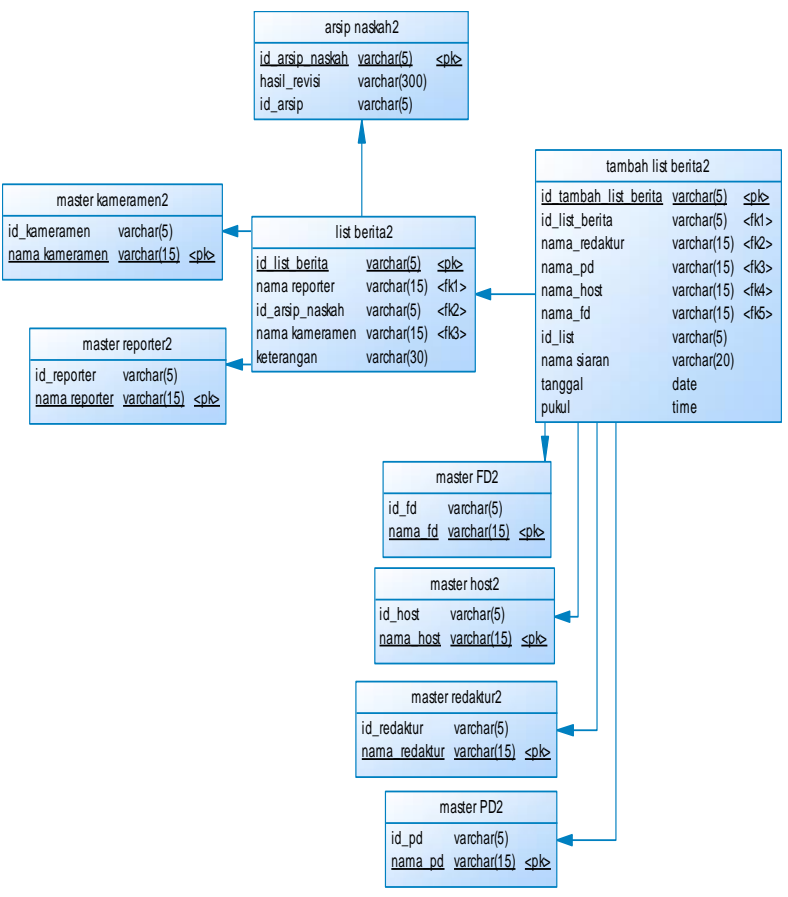

\section{Appendices}

Asumsi dan ketergantungan pada perangkat lunak ini memiliki beberapa faktor ketergantungan yang dapat dijabarkan sebagai berikut.

a. Perangkat lunak berbasis aplikasi desktop atau Desktop Based Application dengan menggunakan bahasa pemrograman $\mathrm{C}++$ yang dijalankan di sistem operasi windows.

b. Dalam menghubungan antar device, diperlukan jaringan LAN atau Local Area Network untuk memaksimalkan keamanan serta kecepatan jaringan

\section{KESIMPULAN}

Dalam laporan praktik kerja lapangan ini dapat di tarik kesimpulan bahwa permasalahan yang ada dalam LPP TVRI Sulawesi Tengah pada Divisi Redaksi berupa pendistribusian naskah dan list berita masih dilakukan secara manual yaitu mengandalkan Microsoft Word dan Microsoft Excel serta pendistribusian item berita yang berisikan video atau gambar hasil liputan reporter dan kameramen yang sudah di edit didistribusikan mengandalkan hard disk dapat dibuatkan suatu perancangan sistem informasi sesuai dengan proses bisnis yang berlangsung.

Dari hasil perancangan tersebut dapat di hasilkan 6 menu dan beberapa menu memiliki sub menu didalamnya. Sehingga operasional perangkat lunak Sistem Informasi Berita pada LPP TVRI Sulawesi Tengah dapat saling terintegrasi satu sama lain.

\section{REFERENSI}

Faslah, R., Satria, B., \& Samponu, Y. B. (2017). Perancangan Learning Management System Menggunakan Object Oriented Design Pada Stmik Widya Cipta Dharma. Jurnal Positif, 3540.

Fridayanthie, E. W., \& Mahdianti, T. (2016). Rancang Bangun Sistem Informasi 
Permintaan Atk Berbasis Intranet

(Studi Kasus: Kejaksaan Negeri

Rangkasbitung). Jurnal Khatulistiwa

Informatika, 126-138.

Hakim, L., Rochimah, S., \& Fatichah, C. (2019). Klasifikasi Kebutuhan NonFungsional Menggunakan Fsknn Berbasis ISO/IEC 25010. Jurnal Ilmiah Teknologi Informasi.

IEEE. (2018). International Standard ISO / IEC / IEEE Systems And Software Engineering - Life Cycle Processes - Requirements Engineering. IEEE Standards.

Melinda, M., Borman, R. I., \& Susanto, E. R. (2017). Rancang Bangun Sistem Informasi Publik Berbasis Web (Studi Kasus: Desa Durian Kecamatan Padang Cermin Kabupaten Pesawaran). Jurnal Tekno Kompak, 1-4.

Prayitno, A., \& Safitri, Y. (2015). Pemanfaatan Sistem Informasi Perpustakaan Digital Berbasis Website Untuk Para Penulis. Indonesian Journal On Software Engineering.

Pujianto. (2012). Analisis Perancangan Sistem Informasi Penjualan Buku Dengan Konsinyasi Berbasis Client Atau Server. Jurnal Informatika, 118127.

Winarni, \& Lestari, R. D. (2019). Sumber Berita Netizen Dalam Perspektif Etika Jurnalistik (Studi Kasus Pada Media Online Jogja.Tribunnews.Com) . Jurnal Pekommas, 85-96.

Yasin, A., MZ, Y., \& Fitriyadi, T. (2015). Analisis Kebutuhan Sistem Informasi Di Lpk Rj-Comp Yogyakarta. Seminar Nasional Informatika.

Yosef, J. (2009). To Be A Joumalist: Menjadi Jurnalis TV, Radio Dan Surat Kabar Yang Profesional. Yogyakarta: Graha Ilmu. 